\title{
A migráció hatása Temerin népességnövekedésére és etnikai szerkezetének átalakulására
}

\section{The effect of migration on the population development and changing ethnic structure of Temerin}

\author{
NAGY IMRE, TÁTRAI PATRIK
}

\section{Bevezetés}

Temerin város az azonos nevű község ${ }^{1}$ székhelye Újvidék (Novi Sad) közvetlen vonzáskörzetében, a tartományi központtól mindössze 20 km-re. A Vajdaság Dél-bácskai körzetének középső részén helyezkedik el, kedvező forgalmi helyzetben. Keleten a zsabljai (Žabalj), északon a szenttamási (Srbobran), nyugaton a verbászi (Vrbas), délen pedig az újvidéki községekkel határos. Temerin község - a székhelyen kívül - magába foglalja még Tiszaistvánfalva (Járek, Bački Jarak) és Bácsszőreg (Szőreg, Hadiknépe, Sirig) településeket is.

Temerin népességszáma az utóbbi bő százötven év során, 1850 és 2011 között három és félszeresére emelkedett. A 2011-es népszámlálás szerint a községben 28287 lakos élt, ${ }^{2}$ míg magában Temerinben 19613 föt számláltak össze.

A lényegében folyamatosnak mondható népességnövekedés egyik legfontosabb forrása a bevándorlás, melyet a 20. század közepéig elsősorban a község kedvező mezőgazdasági adottsága, később pedig a tartományi főváros, Újvidék közelsége indukált. Az a tény, hogy a községből könnyen elérhetőek voltak az újvidéki (főként) ipari üzemek, a múlt század hatvanas-hetvenes éveitől sok betelepülőt vonzott Temerin község településeire. Az ezredfordulót követően pedig a településen mind több újvidéki telepedett le, a közeli, több mint kétszázezer lakosú nagyvárosból kitelepülők számára a viszonylag olcsó ingatlanárak és a vállalkozási lehetőségek egyaránt vonzónak bizonyultak.

Temerin a Tisza menti magyar etnikai tömb déli peremén, a szerb-magyar kontaktzónában helyezkedik el, környezetében azonban elsősorban szerb többségü településeket találunk. Éppen ezért magyar szemszögből nyelvsziget helyzetű településnek tekinthető (1. melléklet). Temerin etnikailag vegyes (szerb és magyar) lakosságú település, amely az 1990-es évek közepéig magyar többségű

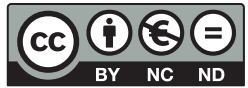


volt. Az etnikai arányok - feszültségekkel és konfliktusokkal kísért - megváltozása az 1990-es évek háborús eseményeihez, elsősorban a szerb menekültek településre érkezéséhez köthető. Temerin neve leginkább mint a szerb-magyar (helyenként nyílt) etnikai konfliktusok színhelye, szimbóluma szerepel többször is a híradásokban.

Tanulmányunkban azt a folyamatot vázoljuk fel, hogy az elmúlt két évszázadban hogyan változott - döntően a migráció hatására - a település etnikai szerkezete, az egyes etnikai csoportok településen belüli megoszlása, és ez mennyiben, milyen módon járulhatott hozzá a - föként fiatalok csoportos utcai és szórakozóhelyi verekedésében megnyilvánuló - többnyire etnikai indíttatású feszültséghez, konfliktushoz.

\section{Migráció és az etnikai szerkezet változásai}

\section{8 előtt}

Temerin etnikai összetétele az elmúlt fél évezredben többször is alapjaiban és meglehetősen gyorsan változott. A középkori, döntően magyarok által lakott település a mohácsi csata időszakában elnéptelenedett, a magyarok helyét a 16. század folyamán főként raškai szerb lakosság foglalta el. A 18. századot megelőzően viszonylag gyér népességszámú település a 18. században leginkább a bevándorlás hatására gyarapodott. A betelepülők a század első felében fóként sajkásvidéki szerbek, később, elsősorban az 1781-1782-es szervezett telepítés alkalmával pedig magyarok (Mészáros 1969, 16.; Ökrész 1999, 112). Ebben az időszakban a szerbek aránya 80\%, a magyaroké $20 \%$ körül mozgott. Az 1780-as évektől a magyarok spontán, nem szervezett bevándorlása jelentős méreteket öltött, így egy évtized leforgása alatt arányuk már a 40\%-ot is elérte (Mészáros 1969). Ebben az időszakban, az 1790-es évek végén jelentek meg az első német (sváb) családok is a településen (Wier 1995, 26.).

A kibontakozó vegyes etnikai kép a Szécsen család 1796-os birtokszerzése után hamar megváltozott. Mivel az új földesúr jobbágysorba akarta kényszeríteni az addig - katonai szolgálatai okán - meglehetős függetlenséget élvező szerb lakosságot, ezért utóbbiak kollektíve úgy döntöttek, hogy a Sajkásvidékre költöznek, ahol 1800-ban új falut alapítottak Gyurgyevó (Sajkásgyörgye, Đurđevo) néven. Az elvándorolt lakosokat szervezett telepítéssel igyekeztek pótolni főként Pest, Heves és Nógrád megyékből (Mészáros 1969, 22.). Így a 19. század elején a falu lakossága már csak római katolikusokból, túlnyomórészt magyarokból és mintegy 30 német családból állt, akik elsősorban Mórról, Császártöltésről és Hajósról érkeztek (Wier 1995, 26.). 
A 19. században a lakosság számának növekedését csak a szabadságharc törte meg. 1848-ban Temerin hadi cselekmények színhelye lett, leégett, lakossága elmenekült és csak 1850-ben tért vissza. Ekkor az osztrák népszámlálás szerint több mint ötezer lakosának 92\%-a magyar, 6,5\%-a német volt. A településen kisebb cigány és zsidó közösség is élt (1. táblázat).

A 19. század második felében a népesség gyarapodása töretlen volt, forrását elsősorban a természetes szaporodás adta, bár a német lakosság bevándorlása is jelentős volt. A bevándorlás mellett 1875 és 1890 között a német lakosság Amerikába vándorlásának első hullámát is regisztrálták, amely főképp a szomszédos Tiszaistvánfalva német lakosságát érintette (Ristanović, Jokić 2006). ${ }^{3}$ A temerini német lakosság száma a 20. század elején, az 1900-as és az 1910-es népszámlálások szerint jelentősen csökkent, ennek hátterében azonban a nyelvi magyarosodás - más (pl. német) megközelítésben magyarosítás (Wier 1995, 30.) - állt. ${ }^{4}$

1. táblázat: Temerin lakosságának etnikai összetétele, 1783-2011 (\%) Ethnic composition of Temerin's population, 1783-2011 (\%)

\begin{tabular}{|c|c|c|c|c|c|c|c|}
\hline \multirow[t]{2}{*}{ 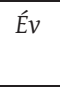 } & \multirow[t]{2}{*}{ A lakosság száma } & \multicolumn{6}{|c|}{ Ebból } \\
\hline & & magyar & német & szerb & jugoszláv & egyéb & összesen \\
\hline 1783 & 1842 & 19,5 & & 80,5 & & 0,0 & 100,0 \\
\hline 1790 & 2923 & 42,8 & & 57,2 & & 0,0 & 100,0 \\
\hline 1799 & 2940 & 45,2 & & 54,8 & & 0,0 & 100,0 \\
\hline 1850 & 5528 & 92,2 & 6,5 & 0,0 & & 1,3 & 100,0 \\
\hline 1857 & 6639 & 93,0 & 6,4 & 0,0 & & 0,6 & 100,0 \\
\hline 1880 & 7865 & 81,2 & 12,9 & 0,2 & & 5,7 & 100,0 \\
\hline 1890 & 8543 & 86,5 & 13,3 & 0,1 & & 0,2 & 100,0 \\
\hline 1900 & 9518 & 91,5 & 8,3 & 0,1 & & 0,1 & 100,0 \\
\hline 1910 & 9768 & 97,2 & 2,4 & 0,3 & & 0,1 & 100,0 \\
\hline 1921 & 9927 & 87,1 & 11,5 & 0,7 & & 0,8 & 100,0 \\
\hline 1931 & 11290 & 77,2 & 9,2 & 12,7 & & 0,9 & 100,0 \\
\hline 1941 & 11035 & 91,2 & 8,1 & 0,3 & & 0,4 & 100,0 \\
\hline 1948 & 11438 & 82,9 &.. & 16,6 & & 0,6 & 100,0 \\
\hline 1953 & 11621 & 80,8 &.. & 17,6 & 0,2 & 1,5 & 100,0 \\
\hline 1961 & 12705 & 78,1 & 0,0 & 20,2 & 0,2 & 1,5 & 100,0 \\
\hline 1971 & 13584 & 73,2 & 0,2 & 24,1 & 1,0 & 1,5 & 100,0 \\
\hline 1981 & 14875 & 65,8 &.. & 28,2 & 4,2 & 1,9 & 100,0 \\
\hline 1991 & 16971 & 55,9 & 0,1 & 35,4 & 5,4 & 3,1 & 100,0 \\
\hline 2002 & 19216 & 42,6 & 0,1 & 50,3 & 1,6 & 5,4 & 100,0 \\
\hline 2011 & 19613 & 37,3 & 0,0 & 55,8 & 0,5 & 6,4 & 100,0 \\
\hline
\end{tabular}

.. = nincs adat. Megjegyzés: 1790-ben és 1799-ben a római katolikusokat magyarként vettük számba, azonban elenyésző hányadban németek és szlovákok is lehetnek közöttük. A 2011-es etnikai összetétel a szerzők becslése a község etnikai adatai alapján. Források: 1790, 1850, 1857: Mészáros 1969; 1799: Ökrész 1999; 1880, 1890, 1900, 1910, 1941: magyar népszámlálások anyanyelvi adatai; 1921, 1931: jugoszláv népszámlálások anyanyelvi adatai; 1948-2011: jugoszláv és szerb népszámlálások nemzetiségi adatai. 


\section{9 és 1991 között}

Az első világháborút követő államhatalom-váltás jelentős változásokat idézett elő az etnikai szerkezetben. Mivel a mai Temerin község területén a szláv lakosság aránya elhanyagolható volt, az új Szerb-Horvát-Szlovén Királyság - biztosítandó a terület hosszú távú birtoklását - kulcsfontosságúnak tekintette a terület délszláv jellegének erősítését (lásd Mirnics 2001). Ezt két módon, a kisebbségek számának csökkentésével, valamint a délszláv nemzetiségek betelepítésével kívánta elérni. Így a főhatalomváltást követően magyar közalkalmazottak, birtokosok, értelmiségiek távoztak nagyobb számban, ami azonban a főként mezőgazdasági jellegű Temerint kevésbé érintette. Ezzel szemben a „szabad“ földterületekre, majorságokba szerb háborús veteránokat, ún. dobrovoljácokat telepítettek. Ilyen telepítés történt 1919-1920-ban Temerin és Tiszaistvánfalva között, ahol 98 külföldi (amerikai és oroszországi szerb) és Bosanska Krajinából, Likából és Hercegovinából származó szerb családot telepítettek le a Fernbachbirtokra. A Temerinhez tartozó új település a Staro Đurđevo (Kolónia) nevet kapta (Danilović, Oklješa, Milojević 1991). ${ }^{5}$ Staro Đurđevóba 1920 és 1941 között 226 szerb családot telepítettek fóként Bosznia-Hercegovinából (118 család), Horvátországból (61), a Vajdaságból (20), Szerbiából (4) és Szlovéniából (2). Az őslakos magyarok és németek, valamint a betelepített szerbek között már a kezdetektől voltak feszültségek, azonban a rendkívül nehéz körülmények közé került telepeseket segítették is a helyiek (Bukurov 1969; Mészáros 1969, 178.). A két világháború közötti időszak másik jelentős telepítésével jött létre 1927-ben Temerin szomszédságában a mai Bácsszőreg település, amelyet elsősorban vajdasági, boszniai, montenegrói és dalmáciai dobrovoljácok népesítettek be (Danilović, Oklješa, Milojević 1991, 8-9.).

Az időszak gazdasági visszaesése, valamint a kisebbségek (magyarok, németek) számára kedvezőtlen földreform és földosztás az 1920-as években a kisebbségek számottevő kivándorlásához vezetett. Temerinből főleg magyar mezőgazdasági munkások távoztak Észak- és Latin-Amerikába, de németek is emigráltak (Temerinből és Tiszaistvánfalváról egyaránt) Észak-Amerikába, Ausztriába és Németországba (Mészáros 1969, 123.). Így jelentősen nőtt a temerini szerb közösség lélekszáma (pár tíz főről másfél ezerre), akik túlnyomórészt Staro Đurđevo településrészen laktak. A magyarok számát a kivándorlás és a németek disszimilációja csökkentette, így lélekszámuk - a magyar uralom időszakához képest - mintegy nyolcszáz fővel csökkent. A németek létszáma - a két világháború közti kivándorlásuk ellenére számottevően nőtt, melyből jelentős azok száma, akik korábban magyarnak vallották magukat (1. táblázat).

1941-ben Magyarország visszaszerezte Bácskát, benne Temerint. A két világháború között érkezett telepeseket elüldözték, többeket meggyilkoltak (Danilović, Oklješa, Milojević 1991, 4-5.), helyükre magyarok kerültek: Bácsszőregre 199 bukovinai (hadikfalvi) székely családot telepítettek, ezért a település új neve Hadiknépe lett. Az 1942. januári újvidéki és sajkásvidéki razzia és vérengzés elérte Temerin zsidó la- 
kosságát is. Mindezek következtében már az 1941-es magyar népszámlálás időpontjában visszaálltak a 30 évvel korábbi etnikai állapotok.

1944-ben a helyzet megfordult. A német csapatok visszavonulásakor a temerini németek 80\%-a elmenekült, csak kevesen várták meg a szerb partizánok bosszúját (Wier 1995, 31.). Ugyanígy elmenekültek a bukovinai székelyek és az 1941 után betelepedett magyarok. A hátramaradt németeket (és a magyarok egy részét) a Tiszaistvánfalván müködő koncentrációs táborba terelték. ${ }^{6} \mathrm{~A}$ túlélő németeket később Németországba deportálták.

A háború és az ismételt hatalomváltás után visszatértek a Bácsszőregről és Staro Đurđevóból 1941-ben elmenekült, elüldözött lakosok (Danilović, Oklješa, Milojević 1991). Az újonnan megüresedett településekre, az elmenekült, kitelepített német és magyar lakosság helyére pedig az akkori néphatalom tervszerüen telepített lakosokat (kolonizáció), hivatalosan gazdasági (földosztás után a földek művelése) és szociális okokkal (szegények, rászorulók birtokhoz juttatása) magyarázva, ám a háttérben a kolonizációnak etnikai indokai is voltak. Az 1945-1948 közötti időszakban a Vajdaságon kívülről 3191 telepes (az 1948-as lakosságszám 21\%-a) érkezett Temerin községbe, túlnyomó többségük a kiürült Tiszaistvánfalvára (2. táblázat) (Đurđev 1995). A telepesek az akkori Jugoszlávia fejletlenebb területeiről, főként Bosznia-Hercegovinából (a Prijedori, Bihaći, Banja Luka-i, Livnói, Drvari járásokból), és Horvátország periferikus területeiről, valamint a Vajdaság más községeiből érkeztek (Ristanović, Jokić 2006, 53.). A telepesek döntően szerb nemzetiségűek voltak.

A háborús események és a migrációs folyamatok hatására ebben az időszakban Temerin népességszáma stagnált. A németek helyét szerb és magyar lakosság foglalta el, így a település etnikai szerkezete egyszerüsödött: magyarok és szerbek éltek csak itt jelentősebb számban.

A kolonizációt követő években a község területére történő betelepülés már spontán, tervszerűtlen volt, de állandósult. Ebben a migrációs hálózatok is szerepet játszottak: a már itt élők hívták és segítették otthon maradt rokonságukat, ismerőseiket a letelepedésben (Bukurov 1969). A bevándorlás az 1950-es évek végén és az 1970-es évek második felében volt a legintenzívebb, ezen időszakok-

2. táblázat: Az 1945 és 1948 között Temerin községbe más tagköztársaságokból érkező telepesek száma településenként

Settlers from other states arriving in Temerin between 1945 and 1948, according to their former place of residence

\begin{tabular}{lcccccc}
\hline Település & A telepe- & A telepesek száma & \multicolumn{4}{c}{ A telepesek származási helye } \\
\cline { 5 - 8 } & sek száma & $\begin{array}{c}\text { a település 1948-as } \\
\text { lélekszámának \%-ában }\end{array}$ & $\begin{array}{c}\text { Bosznia- } \\
\text { Hercegovina }\end{array}$ & $\begin{array}{c}\text { Horvát- } \\
\text { ország }\end{array}$ & Szerbia & Montenegró \\
\hline Temerin & 876 & 7,7 & 712 & 139 & 13 & 12 \\
Tiszaistvánfalva & 2242 & 92,0 & 2190 & 48 & 4 & 0 \\
Bácsszőreg & 73 & 5,3 & 55 & 18 & 0 & 0 \\
\hline
\end{tabular}

Forrás: Đurđev 1995, 87-93. 
ban évente több mint 300 ember érkezett a községbe: főként Tiszaistvánfalvára és Bácsszőregre. A Temerinbe más tagköztársaságokból bevándorló - döntően szerb lakosság elsősorban a kolonista településrészbe, Staro Đurđevóba költözött. A Temerin községbe bevándorlók többsége Bosznia-Hercegovinából származott vagy Horvátországból és a Vajdaság más településeiről érkezett (Đurđev 1995, 105.). Staro Đurđevóban például a Bosznia északnyugati részén fekvő Ključ opštinából származó bevándorlók jelentek meg nagy számban. Összességében az 1948-1991 közötti időszakban a község migrációs egyenlege végig pozitív volt (évi 8-9\%o körül), és az idő előrehaladtával a csökkenő természetes szaporodás miatt egyre nagyobb jelentőségre tett szert a népesség gyarapodásában (Ristanović, Jokić 2006, 56.).

Az időszak etnikai folyamatait áttekintve megállapítható, hogy a spontán migrációnak kiemelt szerepe volt az etnikai arányok eltolódásában. Így 1948 és 1991 között a szerb lakosság száma 1,9 ezerről 6 ezer főre, részaránya 17-ről 35\%ra nőtt. Mindeközben a magyar lakosság száma összességében stagnált (1971-ig enyhén nőtt, utána enyhén csökkent), ami elsősorban csökkenő természetes szaporodásukkal, az 1960-as évek második felétől pedig külföldi munkavállalásukkal magyarázható (Mirnics 1993). Ebben az időszakban mind a Vajdaságban, mind Temerinben egyre népszerübb lett a jugoszláv nemzetiségi kategória, amely 1953tól szerepelt a népszámlálási íveken (Jokić, Ristanović 2006). A magukat jugoszlávnak vallók száma az 1971-es népszámlálástól kezdett el meredeken emelkedni, 1991-ben már a Vajdaság lakosságának 8,7\%-a, Temerin népességének pedig 5,4\%-a vallott jugoszláv nemzetiséget. $\mathrm{E}$ kategória elsősorban a városokban, valamint a kisebbségek - jugoszláviai léptékben különösen a boszniai muzulmánok (Bottlik 2010) - körében vált népszerűvé, ami több okra vezethető vissza. Ezek közül a legfontosabb, hogy egy etnikailag semleges kategóriáról van szó, amely mégis értelmezhető az államhoz való „hűség”, lojalitás megnyilvánulásaként. Így a kisebbségiek számára különösen vonzó volt, hiszen lehetővé tette a kisebbségi státuszból való szimbolikus kiszabadulást, úgy, hogy közben nem kellett az adott tagköztársaság többségéhez tartozónak (a temeriniek esetében szerbnek) vallaniuk magukat. Ugyanígy a vegyes házasságban született gyerekeknek sem kellett választaniuk szüleik nemzetisége közül (lásd Goeke 2007, 158.; Jokić, Ristanović 2006, 396.). Ráadásul a kor pozitív multietnikus tapasztalata egyre többek számára tette vonzóvá ezt a választást. Az 1991-es népszámlálás szerint a két nagyobb etnikai csoport, illetve a jugoszlávok mellett lényegében az összes Vajdaságban honos nemzetiség képviseltette magát a településen, ami a Vajdaságon belüli migráció jelentőségére hívja fel a figyelmet.

\section{1 után}

Az 1991-ben kirobbant polgárháború, Jugoszlávia szétesése, a feléledő nacionalizmusok véget vetettek mind a korábbi évtizedek migrációs jellemzőinek, mind a békés együttélésnek. 1991-2002 között közel hatezer ember telepedett le a 
község településein,7 ami még a második világháború utáni betelepítés mértékét is felülmúlja. Így ezen időszak vándorlási egyenlege a korábbi 8-9\%-es értékről 13,2\%o-re nőtt. Mivel a természetes szaporodás ebben az évtizedben már negatívba fordult, a népesség száma egyedül a bevándorlásnak köszönhetően nőtt.

A bevándorlók többségét a menekültek adták. A 2002-es népszámlálás adatai szerint a község lakosságának 13,5\%-a volt menekült, ami jelentősen meghaladta a vajdasági átlagot (9,2\%) (Ristanović, Jokić 2006, 57.). Temerinbe az 1991 és 1996 közötti időszakban 3444 menekült települt (az 1991-es lakosságszám 20\%-a) (Kocsis, Kicošev 1998), ez a magyar többségü települések közül mind számában, mind arányában kiemelkedő érték. Temerin népszerüsége a menekültek körében két fő okra vezethető vissza. Egyrészt a település urbanizált térségben, kiváló forgalmi helyzetben, Újvidék közelében található, ami megélhetést, boldogulást kínált az érkezőknek (Kocsis, Kicošev 1998). Másrészt fontos szerepet játszottak azok a migrációs hálózatok is, amelyek a megelőző évtizedekben is folyamatosan biztosították a kapcsolatot Temerin és a kibocsátó területek, fóként Bosznia-Hercegovina és Horvátország periferikus, szerblakta részei között. Így nem meglepő, hogy a községben letelepült menekültek 54\%-a Bosznia-Hercegovinából, 44\%-a Horvátországból érkezett. 95\%-uk szerb nemzetiségü volt, a többiek nemzetisége részben ismeretlen, részben vegyes házasságban élő horvát és muszlimán volt (Ristanović, Jokić 2006, 56.).

Ugyanakkor a nagyarányú bevándorlás mellett felerősödött az elvándorlás is. Elsősorban a magyar nemzetiségüek számát apasztotta a katonai behívók, a nacionalista légkör és a háború nyomán fellépő gazdasági válság elől történő külföldre költözés; ráadásul a szelektív migráció révén (főként a fiatalabbak távoztak) fokozódott a helyben maradtak elöregedése. Ennek következtében rendkívüli módon lecsökkent a helyben született népesség aránya. Míg 1981-ben még a község lakosainak 63\%-a helyben született, addig ez 1991-re 58,3\%-ra, 2002-re pedig 49,7\%-ra csökkent (3. táblázat) (Ristanović, Jokić 2006, 53.).

2002 és 2011 között a népesség száma a község egészét nézve stagnált, Temerin esetében enyhén (2\%-kal) nőtt. Részletes statisztikák hiányában csak feltételezhetjük, hogy a népesség gyarapodása mögött még mindig a szerb lakosság bevándorlása áll, hiszen a természetes szaporodás már az 1990-es évek óta negatív tartományba esik, illetve a magyarok kivándorlása tovább folytatódott. ${ }^{8}$

3. táblázat: A Temerin községbe telepedett népesség a letelepedés ideje szerint, a 2002-es népszámlálás időpontjában

Temerin's population in 2002, according to the period of settlement

\begin{tabular}{ccccccccc}
\hline Összlakosság & Helyben & \multicolumn{7}{c}{ Betelepedett lakosság (fö) } \\
\cline { 3 - 9 } & született & 1940 -ig & $1941-1945$ & $1946-1960$ & $1961-1970$ & $1971-1981$ & $1981-1990$ & $1991-2002$ \\
\hline 28275 & 14057 & 118 & 189 & 1689 & 1374 & 1962 & 2523 & 5812 \\
$100,0 \%$ & $49,7 \%$ & $0,4 \%$ & $0,7 \%$ & $6,0 \%$ & $4,9 \%$ & $6,9 \%$ & $8,9 \%$ & $20,6 \%$ \\
\hline
\end{tabular}

Forrás: Ristanović, Jokić 2006. 53. 
4. táblázat: Temerin község főbb nemzetiségeinek lélekszáma és átlagos életkora 2002, 2011 Ethnic structure of Temerin, and average age of the population, 2002, 2011

\begin{tabular}{lcccc}
\hline \multirow{2}{*}{ Nemzetiség } & \multicolumn{3}{c}{2002} & \multicolumn{2}{c}{2011} \\
\cline { 2 - 5 } & Lélekszám (fó) & Átlagos életkor (év) & Lélekszám (fó) & Átlagos életkor (év) \\
\hline Szerb & 18155 & 37,1 & 19112 & 39,7 \\
Magyar & 8341 & 41,7 & 7460 & 43,4 \\
Horvát & 196 & 46,9 & 165 & 53,0 \\
Jugoszláv & 407 & 31,7 & 122 & 43,1 \\
Regionális & 61 & 32,7 & 262 & 32,8 \\
\hline Összesen & 28275 & 38,3 & 28287 & 40,5 \\
\hline
\end{tabular}

Forrás: RZS 2003, 2013 alapján saját szerkesztés.

Az 1991 óta eltelt két évtizedben tehát gyökeresen megváltoztak az etnikai arányok. A szerbek száma a bevándorlás és a menekültek érkezésének hatására ötezer fövel nőtt (azaz majdnem megduplázódott). Ezzel szemben a magyarok száma - a körükben tapasztalható természetes fogyás és elvándorlás következtében - több mint kétezer fővel csökkent. Mindezek következtében a két nemzetiség aránya megfordult, a szerbek abszolút többségbe kerültek (1. táblázat). A folyamat valószínűleg a közeljövőben sem fog megváltozni, hiszen a 2002-es és a 2011-es népszámlálás alapján a magyar (és a többi kisebbségi csoport) elöregedése jelentős, így számuk és arányuk további csökkenése várható - még a migrációs hatások nélkül is (4. táblázat).

A vizsgált időszak másik jelentős változása a jugoszláv nemzetiségűek számának drasztikus (majdnem tizedére történő) visszaesése. Ennek hátterében a polgárháború, a felerősödő nacionalizmus és a jugoszláv állam szétesése állnak - ezáltal pedig szertefoszlottak a pozitív jugoszláv multietnikus tapasztalatok. Ugyanakkor a többes etnikai kötődésűek (pl. vegyes házasságból származók), a kisebbségi származásúak és azok egy része, akik számára az etnicitás nem központi kérdés, egyre inkább új identitáskategóriát választanak maguknak, így növekszik azok száma, akik regionális, vajdasági identitásúnak vallják magukat, illetve akik az etnicitást firtató kérdésre nem válaszolnak. ${ }^{9}$

\section{Temerin etnikai térszerkezetének átalakulása}

A vázolt migrációs és etnikai folyamatok Temerin városképén, morfológiai átalakulásán is nyomon követhetők. A 2. katonai felmérés 1866-ban készült szelvénye szerint a 19. századi Temerin még a mainál jóval kisebb területen, a 19. század legvégén megépített vasúttól északra helyezkedett el (2. melléklet). A lakosság mintegy 10\%-át kitevő németek többsége a település északkeleti részén, a mai Népfront (Narodnog Fronta) utca környékén élt. A 19. század végén, az 1890-es évektől kezdtek el benépesülni és később (a 20. század első felében) összenőni azok a telepek, amelyeket ma Telep néven ismer a helyi lakosság, a központtól északra. 
Az 1919-es államhatalom-váltást követően Temerin és Tiszaistvánfalva között kezdett kiépülni Staro Đurđevo, amely akkor még nem épült egybe Temerinnel. Mindkét világháború után elsősorban ide érkeztek szerb telepesek a földreform keretében. Ugyanakkor a két világháború között és főként a szocializmus időszakában - a migrációs hálózatok hatására - a szerb bevándorlók zöme is ebbe a városrészbe érkezett, így népességszáma a szüken értelmezett Temerinnél dinamikusabban nőtt. A lakosságszám növekedése miatt már az 1970-es évektől fokozatosan egy települési alközpont is kialakult itt, mivel Temerin központja 2-3 km-re helyezkedik el. Napjainkban Staro Đurđevóban több mint ötezren laknak, közülük a magyarok száma alacsony, kb. 100-150 fö, akik többnyire a városrész északi szélén élnek.

A 20. század első felében tehát szegregált térszerkezet alakult ki: északon, a régi városrészben a magyarok, délen, az új részen a szerbek laktak. Ugyanakkor a második világháború után a német lakosság helyét szerb telepesek foglalták el, majd az 1950-es évektől a felélénkülő térbeli mobilitás végleg feloldotta a lakóhelyi szegregációt. Ebben közrejátszottak a szocialista időszakban a város központjában felépített tömbházak, amelyekben ún. szolidaritási lakások voltak, melyeket nagyon olcsón lehetett megkapni különféle politikai, valamint szociális okokból, és ahova elsősorban szerb lakosság költözött, illetve őket költöztették be. ${ }^{10}$ A szocialista időszakban nemcsak vertikálisan (tömbházak), hanem horizontálisan is tovább terjeszkedett a város. Az 1970-es és 1980-as években épültek be például a 22-es blokk, a Nagygyep és a Heréskert nevű részek. Fontos azonban leszögezni, hogy sem ezek a telepek, sem a 2. mellékletben magyar vagy szerb etnikai többséggel ábrázolt egyéb részek nem kizárólagos lakóhelyei az egyes etnikai csoportoknak, azaz nem beszélhetünk etnikailag homogén városrészekről. ${ }^{11}$

A lakóhelyi szegregáció mértéke az 1990-es években a szerb menekültek megjelenésével ismét nőtt, hiszen nagy részük a várostól északra, az újonnan kialakított, hivatalosan Kendergyárnak (Kudeljara), míg a helyiek által csak Šešeljtelepnek (Šešeljgrad) hívott területen lakik. E telep állami és önkormányzati forrásokból épült, ${ }^{12}$ Temerintől pedig egy lakatlan sáv választja el. A menekültek megjelenése egyrészt jelentősen befolyásolta a lakosság demográfiai összetételét, másrészt színre lépésükkel megváltoztak a gazdasági jellemzők is: erősödött az innováció, nőtt a vállalkozások száma (fóként a szolgáltatások és a vendéglátás terén). Ugyanakkor nőtt a munkaerő-kínálat is, amely több esetben konkurenciát jelentett az őshonos helyieknek. Egyes szerzők ebben is látják az etnikai feszültségek okát (Ristanović, Jokić 2006, 57.).

Temerin az elmúlt évtizedben is bevándorlási célterület maradt. A - szerbiai viszonylatban - dinamikusan fejlődő tartományi központ, Újvidék közelsége (munkalehetőségek) és a kedvező helyi gazdasági körülmények fontos vonzó tényezők, a kisvárosi környezet és olcsó ingatlanárak pedig a szuburbanizációt serkentik. Mindezek az etnikai szegregáció ellen ható tényezők, hiszen a régi városrész, a központ üres házaiba a kiköltöző, kihaló magyarok helyére többnyire szerb lakosok költöznek. Így bár napjainkban is megfigyelhető az egyes 
etnikai csoportok területi koncentráltsága, valódi lakóhelyi szegregáció csak a legújabb településrész, a Šešeljtelep esetében figyelhető meg. Utóbbi azonban egyaránt értelmezhető etnikai alapú, valamint őslakos és bevándorló közötti területi elkülönülésként.

\section{Összefoglalás, következtetések}

Az elmúlt bő kétszáz év temerini népességmozgásai többször is alapjában formálták át a település etnikai összetételét. Az elmúlt évszázad migrációs folyamatairól megállapítható, hogy azok jelentősen függtek a hatalmi viszonyoktól és a mindenkori hatalom céljától, amely ebben az időszakban szinte kizárólagosan a nemzetépítést és az etnikai homogenizációt jelentette.

A település etnikai szerkezetének átalakulása meglehetősen gyorsan zajlott/zajlik: ne feledjük, hogy az első világháború előtt szerbek gyakorlatilag nem laktak Temerinben, ma pedig már a lakosság több mint 55\%-át adják. E folyamat azonban nem mehetett volna végbe, ha Temerin nem kínál kedvező életfeltételeket, ha a költözéstől nem lehetett volna pozitív változást remélni az egyéni élethelyzetekben. A 20. század első felében a település kedvező mezőgazdasági adottságai, a század '60-as éveitől elsősorban a helyi ipar és szolgáltatások és egyre inkább Újvidék közelsége jelentették a fó vonzó tényezőt a Jugoszlávia belső perifériáiról érkező telepesek, bevándorlók számára.

A fenti folyamat másik jellemzője, hogy a vándorlás iránya bár követi a fejlettségi különbségeket, mégis etnikai alapú migrációról beszélhetünk, hiszen a letelepedő lakosság döntő többsége boszniai és horvátországi szerb, egyéb nemzetiségek (elsősorban vegyes házasságban élők) a Vajdaságon kívülről alig érkeztek. A helyi szerb közösség alapjait a délszláv állam telepítései teremtették meg, azonban a közösség gyarapodását, a folytatódó bevándorlást a migrációs hálózatok által biztosított információk és segítség alapozták meg.

Felmerül a kérdés, hogy mindez hogyan járul hozzá a Temerinben tapasztalt etnikai feszültségekhez, miért egyedi Temerin e tekintetben, máshol miért nincsenek ilyen súlyos, fizikai agresszióban is kifejeződő problémák.

Véleményünk szerint a magyarázat az etnikai szerkezet gyors átalakulásában keresendő, amely felborította a település korábbi hatalmi viszonyait. A két világháború közötti időszakban a mintegy kilencezer magyarra jutó másfél ezer szerb telepes nem kérdőjelezhette meg a magyarok vezető pozícióját, ráadásul jelentős volt a két nemzetiség közötti térbeli elkülönülés is, amely csökkentette az esetleges súrlódási felületet. A magyarok a későbbi telepítések és bevándorlás időszakában is még három-négyszer annyian voltak, mint a szerbek, így természetes volt, hogy az alapvetően magyar közegben a szerb migránsoknak is alkalmazkodniuk kellett valamilyen mértékben (pl. a magyar nyelv elsajátításával). Ekkor a szegregáció mértéke már csökkent, ami a bevándorlók integráció- 
ját elősegítette. Mindezt támogatta a titói Jugoszlávia felszínen hirdetett és dicsőített multikulturalizmusa, továbbá az a relatív jólét, amely segített áthidalni a felmerülő etnikai alapú problémákat.

A helyzet a délszláv háború kitörésével változott meg gyökeresen. A háború és hatásai (nacionalista légkör kialakulása, gazdasági válság, menekültek érkezése) alapjaiban borította fel az addigi interetnikus viszonyokat és a település etnikai hierarchiáját. Az addigi legnagyobb menekülthullámmal a szerbek kerültek többségbe, így immáron nem volt szükség a magyarok érdekeinek bármilyen figyelembevételére, az újonnan érkezőknek nem kellett a korábbi helyi többséghez (azaz a magyarokhoz) semmilyen módon sem alkalmazkodniuk. Ugyanakkor a menekültek kiváltságos helyzete (pl. külső hatalmi, média- és anyagi támogatás), egy csoportjának gyors előmenetele, erősödő gazdasági pozíciói nemcsak a magyarokban, a helyi szerbekben is aggodalmat keltettek, elsősorban a hatalmi viszonyok megváltozása miatt. A felszínen tehát a menekültek alkalmazkodásának hiánya, „balkáni“ viselkedése a feszültségek forrása, valójában a hatalmi és gazdasági érdekellentétek okoznak problémát.

Három csoport között azonosítható törésvonal: ezek a magyarok, a helyi (egyébként szintén migráns gyökerü) szerbek, valamint a menekült szerbek. Az aktuális érdekek szerint mindig a konfliktus azon oldalát lehet hangsúlyozni, amely az adott csoportnak érdekében áll: etnikai konfliktus magyarok és szerbek között vagy konfliktus az őslakosok és a menekültek között. Ebben a viszonyrendszerben a helyi szerbek jelentik a mérleg nyelvét.

Temerin helyzete a Vajdaságon belül azért egyedi, mert a népesség etnikai szerkezetének átalakulása viszonylag gyorsan zajlott le, illetve a folyamat úgy ment végbe, hogy miközben többezer új lakos érkezett, az őshonos kisebbségiek - kivándorlásuk ellenére is - jelentős számban éltek még a városban. Ráadásul a letelepített menekültek száma és aránya is a legnagyobbak közé tartozik a magyarlakta települések között. Ezek a számottevő és gyors változások teremtették meg a napjainkban is tapasztalható konfliktus alapját.

\section{Jegyzetek}

1 Szerbiában az alapszintű közigazgatási egység a község (opština). Ez olyan területi-közigazgatási egység, amelyben egy központi szerepkörü településhez - ahol a községi képviselő-testület is székel - több település is tartozik. A településeken belül több helyi közösség is létezhet, melyeknek saját statútumuk van, de nem képeznek önálló közigazgatási egységet. Helyi közösségek (mesna zajednica) a helyi lakosság (önkormányzati) érdekérvényesítésére alapíthatók a község területén egy-egy településen vagy településrészen. Temerin község három településből és négy helyi közösségből áll.

2 A statisztikai adatok jelentős része nem áll rendelkezésre Temerin településről, csak Temerin községről, éppen ezért az elemzésben esetenként a községi szintű adatokra támaszkodunk. Utóbbiak esetében mindig jelezzük, hogy az adatok a községre vonatkoznak.

3 Tiszaistvánfalva evangélikus német lakosságát 1787-ben telepítették az akkor Temerinhez tartozó Járekpusztára (Iványi, Virter 1909). A település a második világháború végéig homogén német lakosságú volt. 
4 A magyarosodáshoz (vagy asszimilációhoz) a viszonylag sok vegyes házasság mellett az is hozzájárult, hogy a magyar időszakban Temerin ezer német lakosára nem jutott német iskola. A hatalomváltást követően azonban Temerinben is nyílt német iskola (Wier 1995).

5 A név tisztelgés a 120 évvel korábban Temerint elhagyó szerb lakosok előtt. Staro Đurđevo Temerin része lett (1970 óta a község negyedik helyi közösségét alkotja), ma már teljesen egybeépültek.

6 A szerb partizánok temerini magyar áldozatairól eltérő becslések vannak, a legújabb adatok szerint számuk 300 fö körül lehetett (Csorba 2011).

7 Ugyanakkor az 1990-es évek folyamán a Vöröskereszt adatai szerint mintegy tízezer menekült fordult meg Temerinben, de csak hatezren telepedtek le, a többiek továbbvándoroltak, máshová irányították őket, egy részük pedig visszatért Bosznia-Hercegovinába és Horvátországba. Számuk 1996-ban duzzadt a legnagyobbra, amikor is 6153-an voltak, ezer helyi lakosra 460 menekült jutott (Temerini Újság, 2008. december 18.).

8 Kincses és Takács (2010) vizsgálatai szerint a Magyarországon tartózkodó temerini szerb állampolgárok létszáma 2001-ben 174 fö, míg 2008-ban már 266 fö. A számok elsősorban a nagyságrend érzékeltetésére alkalmasak, a Temerinből Magyarországra áttelepültek pontos számát nem mutatják (pl. halálozás, állampolgárság megszerzése miatt).

9 A vajdasági identitás népszerűségét igazolja az elmúlt két népszámlálás (2002,2011) is, ahol Temerin község egyre több lakosa regionális kötődést vallott a nemzetiséget firtató kérdésre (2002: 61 fo, 2011: 262 fó), hasonlóan a tartományi szintủ folyamatokhoz. Ugyanígy a nemzetiségi kötődést nem deklarálók és az ismeretlenek száma is nőtt (2002: 670 fó, 2011: 753 fö). Ezzel párhuzamosan a jugoszláv nemzetiséget vallók száma drasztikusan csökkent (2002: 407 fó, 2011: 122 fó), így feltételezhetjük, hogy az etnikailag semleges jugoszláv kategória szerepét egyre inkább a regionális (vajdasági) kötődés (illetve a nemzetiségi kötődést vallani nem akarók) kategóriája váltja fel.

10 Több temerini és áttelepült magyar beszélgetőpartnerünk esetében megjelent a Vajdaság (vagy az adott település, pl. Temerin) tudatos, politikailag befolyásolt elszerbesítésnek narratívája. E narratíva szerint mind a világháborúk utáni telepítések, mind a szocialista időszak belső népességmozgása, mind a délszláv háború után a menekültek elhelyezése egyfajta irányított migráció volt, melynek elhallgatott, de egyértelmủ célja az etnikai arányok megváltoztatása volt. A narratíva az etnikai viszonyokat a hatalmi viszonyok függvényében értelmezi, példaként említve, hogy gazdasági és politikai vezető pozícióba csak a többségi nemzet tagjai kerülhettek/kerülhetnek, alkalmasságuktól függetlenül.

11 Ez alól kivételt jelent Staro Đurđevo, ahol a magyarok aránya nem haladja meg a 3\%-ot, valamint a kizárólag menekültek által lakott Šešeljtelep.

12 Az 1990-es évek közepén a menekülteket öt hivatalos és két nem hivatalos központban szállásolták el. Ellátásukról leginkább a község gondoskodott. „A temerini község 50 lakást és hét ikerházat épített számukra, tíz házat adaptált, 223 családot építőanyaggal segített, jelképes összeg ellenében 161 építkezési telket osztott ki és számos kedvezményes hitelt folyósított." (Temerini Újság, 2008. december 18.).

\section{Irodalom}

Bottlik Zs. (2010): Etnikai térfolyamatok háttere Bosznia-Hercegovinában. Földrajzi Közlemények, 4., 443-461.

Bukurov, B. (1969): Neke karakteristika stanovništva opštine Temerin. Zbornik za priodne nauke Matica Srpska, 36., 5-28.

Csorba B. (2011): Szétszórt csontjaink: cikkek, tanulmányok 1944-45-ról. Szerző kiadása, Temerin

Danilović, M., Oklješa, M., Milojević M. (1991): Temerin. Udruženje istraživača tržisšta, Beograd

Đurđev, B. (1995): Posleratno naseljavanje Vojvodine. Matica Srpska, Novi Sad 
Goeke, P. (2007): Transnationale Migrationen. Post-jugoslawische Biografien in der Weltgesellschaft. transcript Verlag, Bielefeld

Iványi I., Virter F. (1909): Bács-Bodrog vármegye községei. In: Borovszky S. (szerk): Bács-Bodrog vármegye. Országos Monográfia Társaság, Budapest

Jokić, I., Ristanović, B. (2006): Uzroci i posledice promena etničke struktura u opštini Temerin u 20. veku. Zbornik Matice Srpske za društvene nauke, 121., 391-398.

Kicošev, S., Wastl-Walter, D., Nagy I., Ristić, D. (2013): Prostorno-urbani razvoj Temerina. Zbornik radova Departman za geografiju, turizam i hotelijerstvo, 41., 134-138.

Kincses Á., Takács Z. (2010): Szerb állampolgárok Magyarországon. Területi Statisztika, 2., 183-197.

Kocsis K., Kicošev, S. (1998): A menekültügy társadalmi-demográfiai aspektusai a Vajdaságban. Regio, 3., 63-74.

Kocsis K., Tátrai P. (2012): A Kárpát-Pannon-térség változó etnikai arculata-Changing Ethnic Patterns of the Carpatho-Pannonian Area. MTA CSFK FI, Budapest

Mészáros S. (1969): Évszázadok viharában: Temerin története 1941-ig. Községi Szkupstina, Temerin

Mirnics K. (1993): Kisebbségi sors. Fórum Kiadó, Újvidék

Mirnics K. (2001): Betelepítések, kitelepítések és vándormozgalmak. In: Gábrity Molnár I., Mirnics Zs. (szerk.): Fészekhagyó vajdaságiak. MTT, Szabadka, 9-75.

Ökrész K. (1999): Míg Temerinbe' magyar szántani fog...: fejezetek egy község múltjából. Fórum Kiadó, Újvidék

Ristanović, B., Jokić, I. (2006): Opština Temerin. Regionalno geografska. Univerztet u Novom Sadu PMF, DGTH, Novi Sad

RZS (2003): Popis stanovništva 2002. Veroispovest, maternji jezik i nacionalna ili etnička pripadnost prema starosti i polu. Republički zavod za statistiku, Beograd

RZS (2013): Popis stanovništva 2011. Veroispovest, maternji jezik i nacionalna pripadnost. Republički zavod za statistiku, Beograd

Wier, W. (1995): Die deutschen Familien von Temerin. Szerző kiadása, Hamm (Schriftenreihe zur donauschwäbischen Herkunftsforschung; 51.) 
1. melléklet: A Vajdaság, illetve Temerin környékének etnikai térképe Ethnic map of Vojvodina and the Temerin area

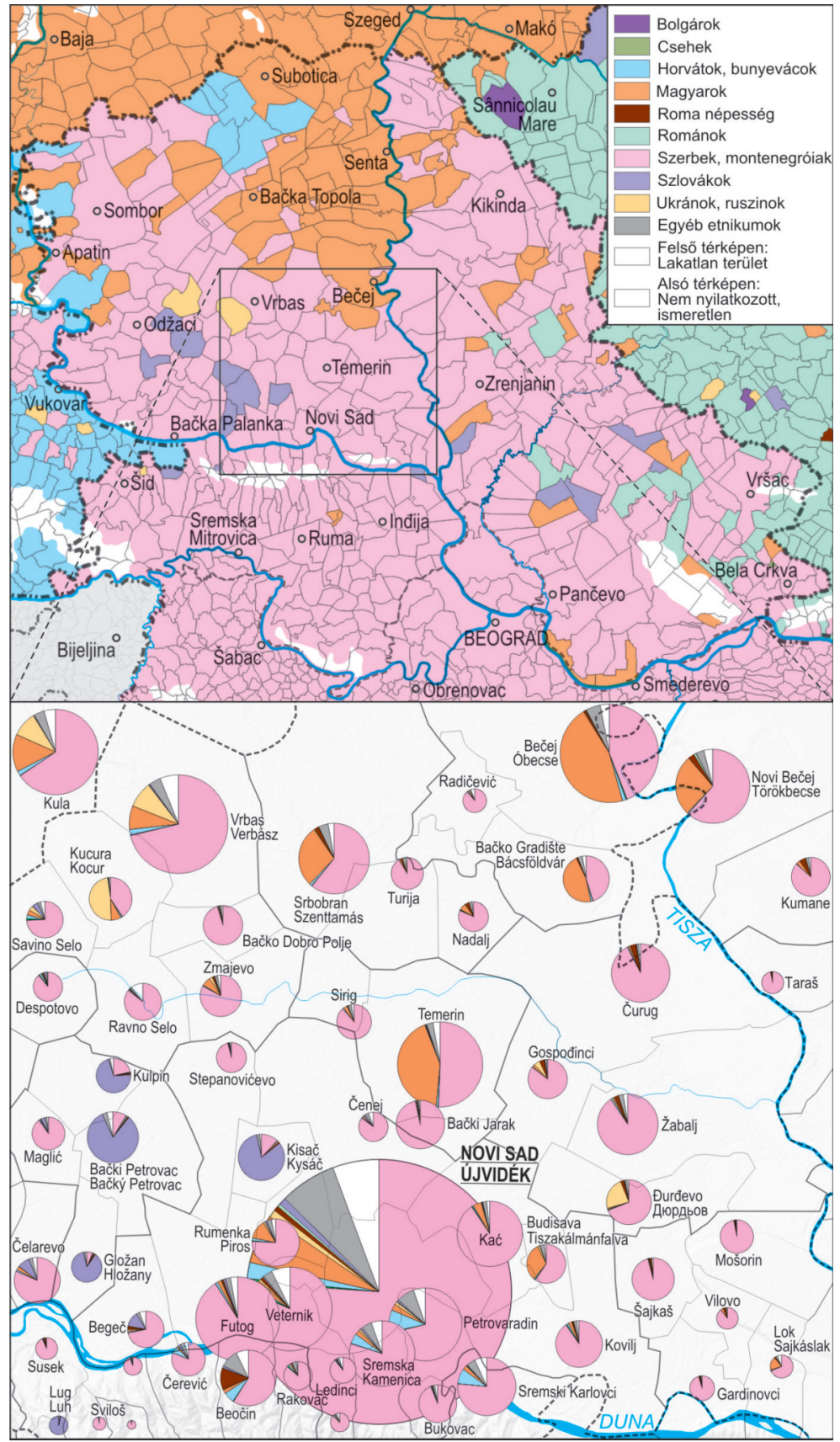

Forrás: Kocsis, Tátrai 2012 
2. melléklet: Az egyes etnikumok elhelyezkedése Temerinben a 21. század elején The location of ethnicities in Temerin at the beginning of 21st century

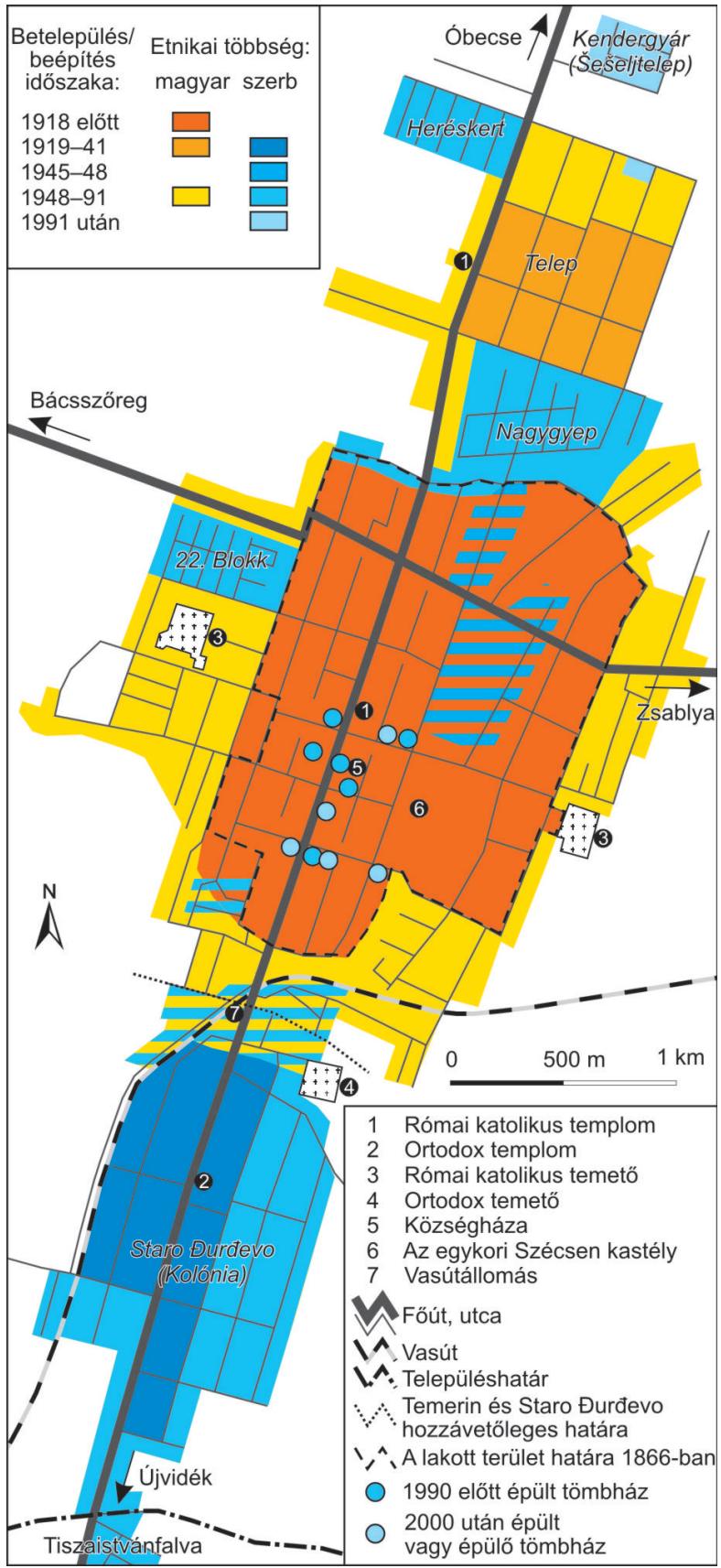

Forrás: Csorba Béla szóbeli közlése, illetve Kicošev, Wastl-Walter, Nagy, Ristić 2013 alapján saját szerkesztés. 